\title{
PANDEMIC INFLUENZA A (H1N1) 2009 PRESENTING AS A MILD DISEASE IN CHILDREN IN A CROATIAN CLINICAL CENTRE
}

\author{
Svjetlana Grgić ${ }^{1,2}$, Elvira Čeljuska-Tošev ${ }^{3}$,Jadranka Nikolić1,2, Filipa Markotić ${ }^{2}$ \\ Mladenka Vukojević2 ${ }^{2}$ Helien Bebek-Ivanković ${ }^{2}$ and Ilija Kuzman ${ }^{2,3}$
}

${ }^{1}$ Department of Infectious Diseases, Mostar University Hospital, Mostar, Bosnia and Herzegovina;

${ }^{2}$ School of Medicine, University of Mostar, Mostar, Bosnia and Herzegovina;

${ }^{3}$ School of Medicine, University of Zagreb, Dr. Fran Mihaljević University Hospital for Infectious Diseases,

Zagreb, Croatia

\begin{abstract}
SUMMARY - Pandemic influenza A virus (H1N1) 2009 causes a disease that is epidemiologically and clinically not significantly different from seasonal influenza, but there are differences. The aim of the study was to display and compare epidemiological and clinical characteristics of pandemic influenza in children. At Dr. Fran Mihaljević University Hospital for Infectious Diseases in Zagreb, in the first two seasons, the incidence of pandemic influenza virus A (H1N1) in particular was exhaustively analyzed only in patients with laboratory-confirmed pandemic influenza A virus (H1N1) 2009. In hospitalized children with documented influenza pandemic, moderate form of the disease predominated, which ultimately meant shorter hospital stay and fewer complications. Otitis media was the rarest complication in children in both seasons. In conclusion, children younger than 5 years, especially boys, were vulnerable groups for pandemic influenza, presenting as a mild disease with low mortality and few complications. Most of the affected children with influenza did not have important risk factors such as asthma and obesity, highlighted by other authors as significant risk factors.
\end{abstract}

Key words: Influenza A virus; H1N1 subtype; Croatia; Risk factors; Child

\section{Introduction}

Influenza (caused by the influenza viruses A, B and C) as the most serious viral disease of the respiratory system is registered in 80,000 to 100,000 patients per year on average in Croatia and in 22,000 patients in the Federation of Bosnia and Herzegovina ${ }^{1-3}$. Influenza rapidly spreads among humans as a droplet infection $^{4}$. The patient is contagious for 5 to 7 days, i.e. two days before the onset of symptoms until the end of temperature elevation, and the immune compromised patients can shed virus for up to three weeks ${ }^{5-8}$. Most

Correspondence to: Svjetlana Grgić, $M D, P h D$, Department of Infectious Diseases, Mostar University Hospital, Kralja Tvrtka bb, 88000 Mostar, Bosnia and Herzegovina

E-mail: svjetlanag@gmail.com

Received March 15, 2018, accepted August 28, 2018 people infected with pandemic virus have a very mild form of the disease, but sometimes it results in serious and fatal disease causing destruction of numerous organ system functions ${ }^{9-14}$. Pandemic virus, apart from complications in the respiratory system, causes complications in other systems as well, such as various neurological syndromes, myocardial degeneration, kidney damage, liver damage, joint damage, etc. It rarely causes secondary bacterial infection ${ }^{9,10,15,16}$. In children, signs of severe disease include apnea, tachypnea, dyspnea, cyanosis, dehydration, altered mental status, and extreme irritability ${ }^{17,18}$. In children hospitalized for influenza, neurological complications are frequent and sometimes life-threatening. In an effort to assess the extent and range of such complications in this population, Australian researchers conducted a study includ- 
ing 506 children younger than 15 years with laboratory-confirmed pandemic influenza A (H1N1) 2009 infection (pH1N1'09) in six pediatric reference centers. Out of 506 patients, 49 (9.7\%) had neurological complications. Patients with neurological complications were older (median age 4.8, range 0.5-12.6 years) compared with 3.7 (0.01-14.9 years) in those without complications. Encephalitis or encephalopathy was present in $1.4 \%$, confusion in $1.0 \%$, loss of consciousness in $1.0 \%$, and paralysis and Guillain-Barré syndrome in $0.4 \%$ of patients; $30.6 \%$ of patients were treated at the Intensive Care Unit (ICU) and 24.5\% required mechanical ventilation. The mean length of hospital stay was 6.5 days and 49 patients died ${ }^{18}$. In September 2009, the World Health Organization (WHO) approved the only valid test for influenza diagnosis, and it is supported by reverse transcriptase polymerase chain reaction (RT-PCR), which has superior sensitivity and differentiation of subtypes and enables phylogenetic analysis ${ }^{19-21}$. Based on clinical features such as chronic diseases, risk factors, dyspnea, the physician can anticipate the possible development of severe forms of the disease, which is useful for clinical decision on patient treatment ${ }^{22}$. However, most people infected with pandemic influenza virus have a very mild form of the disease $e^{1,10,23}$. The mortality rate varies from study to study, depending on the type of study including patient profile, and ranges from $3 \%$ to $45 \% 24-$ ${ }^{26}$. In this pandemic, there are various pulmonary complications and extrapulmonary complications such as myositis, kidney damage, pericarditis, reactive arthritis, myocardial infarction; sometimes there are fatal disease forms with collapse of many organ systems, resulting in greater lethality ${ }^{13,15,24-27}$. There is particular connection of pandemic virus A (H1N1) 2009 with a large number of primary viral pneumonia cases among younger patients, which appears at the beginning of the disease with very fast development and often accompanied by acute respiratory distress syndrome (ARDS) and bacterial pneumonia as a complication $^{15,27}$. In pandemic influenza, there is a number of neurological complications such as epileptic seizures, Reye's syndrome, Guillain-Barré syndrome, cerebellitis, transverse myelitis, acute necrotizing encephalopathy, myelopathy and acute encephalitis, and postinfection encephalitis (acute disseminating encephalomyelitis, ADEM) $)^{27-30}$.

\section{Patients and Methods}

Based on the prospective monitoring of numerous parameters at Dr. Fran Mihaljević University Hospital for Infectious Diseases (UHID) in Zagreb, Croatia, demographic, epidemiological, clinical and basic laboratory indicators of 64 children hospitalized with confirmed influenza A ( $\mathrm{pH} 1 \mathrm{N1}$ '09) virus infection diagnosis between July 1, 2009 and March 31, 2010 (pandemic season) were retrospectively analyzed. The same set of data was collected and analyzed for 44 children hospitalized for influenza A ( $\mathrm{pH} 1 \mathrm{N1}$ '09) virus infection in the subsequent season, from November 15, 2010 to March 31, 2011 (post-pandemic season). Patient data were collected from medical records. The patients were stratified according to age, sex, date of admission to the hospital, duration of the disease preceding hospitalization (in days), and length of hospital stay (in days). Symptoms of the disease including their severity, complications and final outcome, risk factors, basic laboratory results (together with chest radiographs), and applied treatment were analyzed. Ethical approval was obtained from the Ethics Committee of Dr. Fran Mihaljević University Hospital for Infectious Diseases from Zagreb.

\section{Classification of disease severity}

Disease severity was classified into four categories (internal coding) according to clinical presentation, accompanying chronic diseases, complications, and final outcome, as follows: (1) mild (as a rule, without complications and chronic diseases); (2) moderate (complications and/or aggravation of chronic diseases); (3) severe (treated at ICU); and (4) very severe (fatal outcome). Risk factors and complications due to influenza A ( $\mathrm{pH} 1 \mathrm{N1}$ '09) were defined according to the International Classification of Diseases $-10^{\text {th }}$ Revision (ICD-10) and UHID internal coding. Due to its importance, diabetes was classified as an exceptional risk factor. The term encephalopathy was used generally for all disorders of consciousness, including primary and secondary affection of the central nervous system.

\section{Laboratory testing}

Clinical criteria for diagnosing influenza were presenting symptoms (high fever, headache, fatigue, muscle and joint aches, cough), together with indicative 
(highest recorded values) laboratory tests (C-reactive protein [CRP], erythrocyte sedimentation rate [ESR], leukocyte count [L]), and epidemiological data. Laboratory testing with basic biochemical analysis (blood glucose level, urea, creatinine, liver enzymes [AST, ALT, GGT, LDH]) was performed in all patients, and creatine kinase $(\mathrm{CK})$ was analyzed in half of the patients using Olympus AU640 and/or Olympus AU400 automated biochemistry analyzers (Hamburg, Germany). All patients underwent chest radiography and $85 \%$ of them electrocardiography (ECG). Any deviation from normal electrocardiogram, with or without pharmacological treatment, was considered as a sign of pathologic ECG.

Respiratory samples (pharyngeal swab and/or bronchoalveolar aspirate) were analyzed and tested using RT-PCR in the Croatian National Influenza Centre, which exchanges information with the Influenza Centre in London ${ }^{31}$.

\section{Statistical analysis}

Statistical analysis included Kolmogorov-Smirnov test to assess equality of the distribution of continuous variables. To describe their grouping and dispersion, median and interquartile range were used for distribution of data that deviated significantly from the normal. The two asymmetrically distributed independent variables were compared using Mann-Whitney $U$ test. To analyze difference in the proportions of nominal and ordinal variables, the $\chi^{2}$-test was used, and in the lack of expected frequency, Fisher exact test was additionally applied. The probability of error was set at $\alpha<0.05$, and differences between the groups were accepted as statistically relevant at $p<0.05$. Statistical analysis was performed using SPSS software version 17.0 and Microsoft Excel version $11^{32}$.

\section{Results}

Epidemiological features of pandemic influenza and differences in the incidence in the first two seasons in Croatia are shown in Table 1. During the pandemic season, there were 64 (37.9\%) hospitalized children aged $\leq 18$ years with proven influenza $A$ virus, whereas during the post-pandemic season there were 44 (26\%) hospitalized children $\left(\chi^{2}\right.$-test $\left.=5.113, \mathrm{df}=1, \mathrm{p}<0.023\right)$.

Distribution of hospitalized children with confirmed influenza A (pH1N1'09) according to age
Table 1. Epidemiological features of influenza $A$ ( $p$ H1N1'09) virus infection during pandemic and post-pandemic seasons

\begin{tabular}{|l|l|l|}
\hline Feature & $\begin{array}{l}\text { Pandemic } \\
\text { season }\end{array}$ & $\begin{array}{l}\text { Post-pandemic } \\
\text { season }\end{array}$ \\
\hline Outbreak & July 2009 & $\begin{array}{l}\text { December } \\
2010\end{array}$ \\
\hline $\begin{array}{l}\text { Duration } \\
\text { of the epidemic }\end{array}$ & 9 months & 4 months \\
\hline Peak of the epidemic & November 2009 & January 2011 \\
\hline $\begin{array}{l}\text { Number of examined } \\
\text { /hospitalized }\end{array}$ & $3856 / 562$ & $2883 / 458$ \\
\hline $\begin{array}{l}\text { Hospitalized with } \\
\text { confirmed infection }\end{array}$ & 169 & 167 \\
\hline Children: n (\%) & $64(37.9)$ & $44(26.4)$ \\
\hline $\begin{array}{l}\text { Most common } \\
\text { complication }\end{array}$ & $\begin{array}{l}\text { Primary viral } \\
\text { pneumonia }\end{array}$ & $\begin{array}{l}\text { Bacterial } \\
\text { pneumonia }\end{array}$ \\
\hline $\begin{array}{l}\text { Died with confirmed } \\
\text { infection: } \mathrm{n}(\%)\end{array}$ & $4(2.4)$ & $9(5.3)$ \\
\hline $\begin{array}{l}\text { Mean age of } \\
\text { deceased (yrs) }\end{array}$ & $35.3 \pm 7.8$ & $44.7 \pm 16.3$ \\
\hline
\end{tabular}

Table 2. Age distribution of children with influenza $A$ (pH1N1'09) virus infection during pandemic and postpandemic seasons

\begin{tabular}{|l|l|l|l|l|}
\hline $\begin{array}{l}\text { Age group } \\
\text { (yrs) }\end{array}$ & $\begin{array}{l}\text { Pandemic season } \\
\mathrm{n}(\%)\end{array}$ & $\begin{array}{l}\text { Post-pandemic season } \\
\mathrm{n}(\%)\end{array}$ \\
\hline$<1$ & 11 & 6.5 & 13 & 7.8 \\
$1-2$ & 12 & 7.1 & 7 & 4.2 \\
$3-6$ & 16 & 9.5 & 13 & 7.8 \\
$7-14$ & 21 & 12.4 & 9 & 5.4 \\
$15-17$ & 4 & 2.4 & 2 & 1.2 \\
\hline Total & 64 & 37.9 & 44 & 26.4 \\
\hline
\end{tabular}

groups in the first two seasons is shown in Table 2. In the pandemic season, children aged 7-14 were most commonly affected, with 21 (12.4\%) cases in children. In the post-pandemic season, there were 13 (7.8\%) cases aged 0-12, precisely 3-6 years.

Clinical and laboratory features of children with influenza A H1N1pdm09 virus infection during pandemic and post-pandemic seasons are shown in Table 3. In the pandemic and post-pandemic seasons, the mean age of hospitalized children ( $0-17$ age group) was $4.5 \pm 8.0$ and $3.5 \pm 7.0$ years, respectively (MannWhitney $U=1174.00, p=0.140$ ). In the first season, 
Table 3. Clinical and laboratory features of children with influenza A (pH1N1'09) virus infection during pandemic and post-pandemic seasons

\begin{tabular}{|l|l|l|l|}
\hline & Pandemic season & $\begin{array}{l}\text { Post-pandemic } \\
\text { season }\end{array}$ & \\
\hline Clinical feature & $\begin{array}{l}\text { Median } \\
\text { [interquartile range }\end{array}$ & $\begin{array}{l}\text { Median } \\
\text { [interquartile range] }\end{array}$ & $\begin{array}{l}\text { p } \\
\text { (Mann-Whitney U) }\end{array}$ \\
\hline Mean age (yrs) & $4.5[8]$ & $3.5[7]$ & 0.140 \\
Duration of disease prior to hospitalization (days) & $3.0[1]$ & $4.0[3]$ & $0.001^{*}$ \\
Length of hospital stay (days) & $4.0[3]$ & $6.0[3]$ & $0.013^{*}$ \\
Mean maximum temperature ( $\left.{ }^{\circ} \mathrm{C}\right)$ & $39.5[0.8]$ & $39[0.8]$ & 0.276 \\
Erythrocyte sedimentation rate $(\mathrm{mm} / \mathrm{h})$ & $15[14]$ & $20[28]$ & 0.326 \\
Leukocyte count $\left(\mathrm{x} 10^{9} / \mathrm{L}\right)$ & $8.5[4.9]$ & $9.5[9.3]$ & 0.480 \\
C-reactive protein $(\mathrm{mg} / \mathrm{L})$ & $46.6[55.7]$ & $48.7[61.0]$ & 0.827 \\
Creatine kinase (U/L) & $91[75]$ & $134[246]$ & 0.374 \\
Laboratory findings & $\mathrm{n}(\%)$ & $\mathrm{n}(\%)$ & $\mathrm{p}\left(\chi^{2}\right)$ \\
Liver damage & $6(9.4)$ & $7(15.9)$ & 0.486 \\
Abnormal electrocardiography & $18(28.2)$ & $14(31.8)$ & 0.075 \\
Patients treated with antiviral agents & $43(67.2)$ & $36(81.8)$ & 0.092 \\
Patients treated with antibiotics & $23(35.9)$ & $21(47.7)$ & 0.220 \\
Patients treated in Intensive Care Unit & $13(20.3)$ & $4(9.1)$ & 0.220 \\
Died & 0 & $1(2.3 \%)$ & 0.226 \\
\hline Total & $64(37.9 \%)$ & $44(26.4 \%)$ & \\
\hline
\end{tabular}

*Statistically significant $(\mathrm{p}<0.05)$

there were $37(57.8 \%)$ boys and $27(42.2 \%)$ girls, 11 $(17.2 \%)$ of them infants. In the second season, there were 27 (61.4\%) boys and 17 (38.6\%) girls, 13 (29.5\%) of them infants.

In the first season, the mean duration of the disease before hospitalization was 3.0 \pm 1.0 (range 1-7) days, whereas in the second season it was $4.0 \pm 3.0$ (range 1-11) days, which was statistically significant (MannWhitney $\mathrm{U}=837.00$, $\mathrm{p}<0.001$ ).

The mean length of hospital stay in children with pandemic influenza virus A was 4.0 \pm 3.0 (range 1-33) days in the pandemic season and 6.0 \pm 3.0 (range 2-26) days in the post-pandemic season, which also was statistically significant (Mann-Whitney $U=990.00$, $\mathrm{p}<0.013$ ). The mean highest body temperature in hospitalized children and mean ESR are shown in Table 3.

The mean leukocyte count on children admission to the hospital was $8.5 \pm 4.9 \times 10^{9} / \mathrm{L}$ (range 0.9 to $\left.55.7 \times 10^{9} / \mathrm{L}\right)$ in the pandemic season and $9.5 \pm 9.3 \times 10^{9} / \mathrm{L}$ (range 1.8 to $34.0 \times 10^{9} / \mathrm{L}$ ) in the post-pandemic season (Mann-Whitney U=1295.00; $\mathrm{p}=0.480$ ). The mean $\mathrm{CRP}$ value in the pandemic season was $46.6 \pm 55.7$ (range 0.3 to 496 ) $\mathrm{mg} / \mathrm{L}$ and $48.7 \pm 61.0$ (range 0.1 to 190) $\mathrm{mg} / \mathrm{L}$ in the post-pandemic season (MannWhitney $U=1373.00 ; p=0.827$ ).

In the pandemic season, CK was determined in $14 / 64$ children, with the mean value of $91.0 \pm 75.0$ (range 5-476) U/L. In the post-pandemic season, CK was determined in 18/44 children, with the mean value of 134.0 \pm 246.0 (range 32-877) U/L (Mann-Whitney $\mathrm{U}=70.00 ; \mathrm{p}=0.374)$. Although the $\mathrm{CK}$ value was considerably higher in the post-pandemic season, the difference was not statistically significant. Liver damage was recorded in 6/64 (9.4\%) children in the pandemic season and in $7 / 44(15.9 \%)$ children in the post-pandemic season $\left(\chi^{2}\right.$-test $=0.485, \mathrm{df}=1, \mathrm{p}=0.486$, Fisher exact test).

Abnormal ECG findings were reported more frequently in children in the first season $(18 / 144 ; 12.5 \%)$ as compared to the second season $(14 / 150 ; 9.3 \%)$, however, without statistically significant difference $\left(\chi^{2}\right.$ test $=3.175, \mathrm{df}=1, \mathrm{p}=0.075$, Fisher exact test).

In the pandemic season, 43/64 (67.2\%) hospitalized children were treated with oseltamivir. In the 
Table 4. Disease severity in children with influenza $A$ (pH1N1'09) virus infection during pandemic and post-pandemic seasons

\begin{tabular}{|l|l|l|l|}
\hline \multirow{2}{*}{$\begin{array}{l}\text { Clinical form } \\
\text { of disease }\end{array}$} & $\begin{array}{l}\text { Pandemic } \\
\text { season }\end{array}$ & $\begin{array}{l}\text { Post-pandemic } \\
\text { season }\end{array}$ & \multirow{2}{*}{$\mathrm{p}\left(\chi^{2}\right)$} \\
\cline { 2 - 4 } & $\mathrm{n}(\%)$ & $\mathrm{n}(\%)$ & \\
\hline Mild & $19(29.7)$ & $6(13.6)$ & 0.987 \\
Moderate & $32(50.0)$ & $32(50.0)$ & 0.651 \\
Severe & $13(20.3)$ & $3(6.8)$ & 0.846 \\
Very severe & 0 & $3(6.8)$ & $0.036^{*}$ \\
\hline Total & 64 & 44 & \\
\hline
\end{tabular}

*Statistically significant $(\mathrm{p}<0.05)$

Table 5. Risk factors in children with influenza $A$ (pH1N1'09) virus infection during pandemic and post-pandemic seasons

\begin{tabular}{|c|c|c|c|}
\hline \multirow[t]{2}{*}{ Risk factor } & $\begin{array}{l}\begin{array}{l}\text { Pandemic } \\
\text { season }\end{array} \\
\end{array}$ & $\begin{array}{l}\text { Post-pandemic } \\
\text { season }\end{array}$ & $\mathrm{p}\left(\chi^{2}\right)$ \\
\hline & $\mathrm{n}(\%)$ & $\mathrm{n}(\%)$ & \\
\hline $\begin{array}{l}\text { Chronic heart } \\
\text { disease }\end{array}$ & $4(6.25)$ & $1(2.3)$ & 0.338 \\
\hline Asthma & $6(9.37)$ & $3(6.8)$ & 0.346 \\
\hline $\begin{array}{l}\text { Chronic } \\
\text { obstructive } \\
\text { pulmonary } \\
\text { disease }\end{array}$ & $4(6.25)$ & 0 & 0.091 \\
\hline Hypertension & $1(1.5)$ & $3(6.8)$ & 0.228 \\
\hline $\begin{array}{l}\text { Immunological } \\
\text { disorder }\end{array}$ & $6(9.4)$ & $8(18.2)$ & 0.180 \\
\hline $\begin{array}{l}\text { Malignant } \\
\text { disease }\end{array}$ & $1(1.5)$ & $1(2.3)$ & 0.788 \\
\hline $\begin{array}{l}\text { Chronic kidney } \\
\text { disease }\end{array}$ & $1(1.5)$ & 0 & 0.404 \\
\hline $\begin{array}{l}\text { Neuromuscular } \\
\text { disease }\end{array}$ & $9(14)$ & $2(4.5)$ & 0.102 \\
\hline $\begin{array}{l}\text { Diabetes } \\
\text { mellitus }\end{array}$ & $1(1.5)$ & $1(2.3)$ & 0.788 \\
\hline Obesity & $1(1.5)$ & $1(2.3)$ & 0.404 \\
\hline $\begin{array}{l}\text { Congenital } \\
\text { deformity }\end{array}$ & $5(7.8)$ & $3(6.8)$ & 0.845 \\
\hline Total & $39(60.9)$ & $23(52.3)$ & \\
\hline
\end{tabular}

post-pandemic season, 36/44 (81.8\%) children were administered oseltamivir. Compared to the pandemic season, the majority of children were treated with oseltamivir in the post-pandemic season, with no statistically significant difference $\left(\chi^{2}\right.$-test $=2.842, \mathrm{df}=1, \mathrm{p}=$
Table 6. Distribution of complications in children with influenza A (pH1N1'09) virus infection during pandemic and post-pandemic seasons

\begin{tabular}{|c|c|c|c|}
\hline \multirow[t]{2}{*}{ Complication } & \begin{tabular}{|l} 
Pandemic \\
season
\end{tabular} & $\begin{array}{l}\text { Post-pandemic } \\
\text { season }\end{array}$ & \multirow[t]{2}{*}{$p\left(\chi^{2}\right)$} \\
\hline & $\mathrm{n}(\%)$ & n (\%) & \\
\hline $\begin{array}{l}\text { Primary viral } \\
\text { pneumonia }\end{array}$ & $10(15.6)$ & $6(3.6)$ & 0.774 \\
\hline $\begin{array}{l}\text { Bacterial } \\
\text { pneumonia }\end{array}$ & $8(12.5)$ & $10(22.7)$ & 0.160 \\
\hline Liver damage & $6(9.4)$ & $5(11.4)$ & 0.736 \\
\hline Myositis & $7(10.9)$ & $2(4.5)$ & 0.237 \\
\hline Encephalopathy & $4(6.3)$ & $2(4.5)$ & 0.704 \\
\hline $\begin{array}{l}\text { Acute } \\
\text { bronchitis }\end{array}$ & $4(6.3)$ & - & 0.091 \\
\hline Kidney damage & - & $2(4.5)$ & 0.085 \\
\hline $\begin{array}{l}\text { Acute } \\
\text { respiratory } \\
\text { distress } \\
\text { syndrome }\end{array}$ & - & $1(2.3)$ & 0.225 \\
\hline Sinusitis & $4(6.3)$ & $2(4.5)$ & 0.704 \\
\hline $\begin{array}{l}\text { Febrile } \\
\text { convulsions }\end{array}$ & $5(7.8)$ & $2(4.5)$ & 0.498 \\
\hline Otitis media & $2(3.1)$ & $1(2.3)$ & 0.791 \\
\hline Bronchiolitis & $2(3.1)$ & $4(9.1)$ & 0.170 \\
\hline $\begin{array}{l}\text { Other } \\
\text { complications }\end{array}$ & $9(14)$ & 7 (15.9) & 0.791 \\
\hline Total & 61 & 44 & \\
\hline
\end{tabular}

0.092, Fisher exact test). Antibiotics were used in 23/64 (35.9\%) hospitalized children in the first season and in 21/44 (47.7\%) children in the second season $\left(\chi^{2}\right.$-test $=1.501, \mathrm{df}=1, \mathrm{p}=0.220$, Fisher exact test $)$. In the ICU, $13(20.3 \%)$ children with proven virus were treated with antibiotics in the first season and four (9.1\%) children in the second season $\left(\chi^{2}\right.$-test $=1.503$, $\mathrm{df}=1, \mathrm{p}=0.220$, Fisher exact test) (Table 3 ).

Disease severity in children with influenza A (pH1N1'09) virus infection during the pandemic and post-pandemic seasons is shown in Table 4. In the first season, there were no children with very severe disease, whereas there were three $(6.8 \%)$ such cases in the second season, which was significantly higher $\left(\chi^{2}=4.419\right.$, $\mathrm{df}=1, \mathrm{p}<0.036$, Fisher exact test) (Table 4).

Risk factors in children with influenza A (pH1N1'09) virus infection during the pandemic and post-pandemic seasons are shown in Table 5. 
In the pandemic season, there were $27 / 64$ (42.2\%) children with risk factors and 37/64 (57.8\%) without risk factors. In the post-pandemic season, there were $34(77.3 \%)$ children without risk factors and only 10 (22.7\%) with risk factors. In 27/64 (42.2\%) children with confirmed influenza A (pH1N1'09) hospitalized in the pandemic season, there were 39 risk factors or a mean of 1.4 risk factors per patient. In 10/44 (22.7\%) children hospitalized in the post-pandemic season, there were 23 risk factors or a mean of 2.3 risk factors per patient.

A significantly higher number of risk factors were recorded in hospitalized children in the pandemic season compared to the post-pandemic season $\left(\chi^{2}-\right.$ test $=4.383, \mathrm{df}=1, \mathrm{p}<0.036$, Fisher exact test). Neuromuscular diseases were most common, found in $9 / 64$ (14.1\%) children, followed by asthma and damage to the immune system in 6/64 (9.4\%), congenital deformities in 5/64 (7.8\%), and chronic heart disease and obstructive pulmonary disease in $4 / 64(6.3 \%)$ children. In the post-pandemic season, the most common risk factor in hospitalized children was immunodeficiency in 8/44 (18.2\%) children, followed by hypertension, asthma and congenital deformities in 3/44 (6.8\%) and neuromuscular disease in 2/44 (4.5\%) children. There was no statistically significant difference $\left(\chi^{2}\right.$-test $=14.547, \mathrm{df}=10$, $\mathrm{p}=0.149$, Fisher exact test) in the occurrence of risk factors in hospitalized children with pandemic influenza between the two seasons (Table 5).

Distribution of complications in the children with influenza A ( $\mathrm{pH} 1 \mathrm{N1}$ '09) virus infection during the pandemic and post-pandemic seasons is shown in $\mathrm{Ta}^{-}$ ble 6. In the pandemic season, there were 35/64 (54.7\%) hospitalized children with confirmed influenza A (pH1N1'09). In these patients, 61 complications were recorded, yielding a mean of 1.7 complications per patient, whereas 29 (45.3\%) children were free from complications. In the post-pandemic season, there were 20/44 (45.5\%) hospitalized children with 44 complications, yielding a mean of 2.2 complications per patient, whereas 24 (54.5\%) children had no complications. There was no statistically significant difference in the number of hospitalized children with complications $\left(\chi^{2}\right.$-test $=0.048, \mathrm{df}=1, \mathrm{p}<0.826$, Fisher exact test) between the two seasons.

The children hospitalized during the pandemic season developed a greater number of viral than bacterial pneumonia (10 vs. 8); in the post-pandemic season, the bacterial to viral pneumonia ratio was 10:6.
In the pandemic season, the most common complication in children was primary viral pneumonia in 10 (15.6\%) and bacterial pneumonia in eight (12.5\%) children, followed by myositis in nine (14.0\%) cases in the first season and seven (10.9\%) cases in the second season. The rarest complications were otitis media and bronchiolitis, which occurred in two (3.1\%) patients. The most common complication in hospitalized children in the post-pandemic season was bacterial pneumonia in $10(22.7 \%)$ cases, followed by other complications in seven (15.9\%) and liver damage in five (11.4\%) children. The rarest complications in the second season were otitis media and acute respiratory distress syndrome, in one (2.3\%) child each (Table 6).

\section{Discussion}

In our study, a smaller number of children were hospitalized and had a significantly lower number of risk factors and complications compared with adults. In comparison to post-pandemic season, a greater number of children were hospitalized during the pandemic season (37.9\% vs. 26.4\%), which is consistent with the reports from the UK where $36 \%$ of children were hospitalized in the pandemic season ${ }^{33,34}$. In our study, the children hospitalized in both seasons were significantly younger (4.5 and 3.5 years) compared to the results reported by Wiechinga et al. from Germany, where the mean age of children was seven years ${ }^{35}$. In both seasons, boys were more likely to acquire the disease, similar to the results reported from Germany, France and the United States ${ }^{35-37}$. In the pandemic season, the mean duration of illness prior to admission was three days, and in the post-pandemic season four days, which obviously resulted in longer hospital stay (6.0 vs. 4.0 days) in the former, particularly due to the development of a number of bacterial complications ${ }^{38}$. Therefore, in the post-pandemic season, more inflammatory parameters (ESR, leukocyte count, CRP), CK and aminotransferases and more frequent use of antibiotics ( $47.7 \%$ vs. $35.9 \%)$ were recorded. In both seasons, antiviral drugs (81.8\% and 67.2\%) were used, which was similar to the results from other European centers $^{35,36}$.

In the post-pandemic season, significantly more children were treated in the ICU as compared to the pandemic season (20.3\% vs. 9.1\%). The percentage of ICU treatment in the pandemic season was consistent 
with the results reported by Gastañaduy and Bégué (9\%), but higher than reported by German authors $(6 \%)^{35,36}$. In the post-pandemic season, the incidence of severe forms of disease and mortality in hospitalized children was extremely low (2.3\%), even in those with risk factors for development of complications, which was consistent with the reports from Spain and Chi$\mathrm{na}^{39,40}$. Most of our children were free from risk factors in both seasons ( $57.8 \%$ and $77.3 \%$ ), as also found in several American and European centers ${ }^{41,42}$.

There was no significant difference in the prevalence of risk factors in hospitalized children, but most common were neuromuscular diseases $(14.1 \%$ and 4.5\%), followed by asthma (9.4\% and 6.8\%) and damage to the immune system (9.8\% and $18.2 \%)$. In our patients, obesity was not frequent (1.5\% and $2.3 \%)$, whereas German authors noted a greater number (43\%) of obese children and marked obesity as an important risk factor ${ }^{35}$. The most common complication in children was primary viral pneumonia $(15.6 \%$ vs. $3.6 \%)$ in the first season and bacterial pneumonia $(22 \%$ vs. $12.5 \%)$ in the second season. In our setting, there were complications such as encephalopathy, neurological disorders and gastroenteritis, which are reported by Chen $e a^{40}$. Otitis media as the most common complication of influenza in children was rarely observed, which can be explained by the fact that pandemic influenza generally has less bacterial complications ${ }^{42,43}$. Unlike the US and some European reports, we had very few children hospitalized in both seasons and they had a significantly lower number of risk factors and complications compared with adults ${ }^{43}$.

Seasonal influenza A in children had a low mortality but high morbidity, many complications and an increased number of hospitalizations, especially in children with risk factors. In children, pandemic influenza presented as a mild disease with low mortality and few complications. Comparing with seasonal influenza, children infected with pandemic strain of the virus had more respiratory complications, a significantly higher number of viral and secondary bacterial pneumonia, and frequent need for mechanical ventilation. In children with pandemic influenza, encephalopathy is more common than in seasonal influenza ${ }^{43}$. In conclusion, in the post-pandemic season, sick children were more frequently hospitalized later in the course of the disease, when bacterial complications had already developed, and hospital stay was significantly longer com- pared to the previous season. In hospitalized children with evidence for pandemic influenza, the medium severe form of the disease prevailed, which ultimately meant shorter hospital stay and fewer complications. Complications in hospitalized children with confirmed influenza A (pH1N1'09) in the first two seasons were not statistically significant. The most common complication of influenza in children was primary viral pneumonia in the pandemic season and bacterial pneumonia in the post-pandemic season. The rarest complication in children was otitis media in both seasons.

\section{Conclusion}

Children younger than 5 years, especially boys, are vulnerable groups for pandemic influenza. In our patients, pandemic influenza presented as a mild disease with low mortality and few complications. Most of the affected children with influenza did not have important risk factors such as asthma and obesity, which other authors point out in their studies as significant risk factors.

\section{Acknowledgments}

We thank all staff members of Dr. Fran Mihaljević University Hospital for Infectious Diseases, Zagreb, who participated or helped in the study. Special thanks go to Professor Matko Marušić and Dr Mersiha Mamić-Kaknjo for advice and support in preparing this article.

\section{References}

1. Kuzman I. Virusi influence. U: Kuzman I. Pneumonije - uzročnici, dijagnostika i liječenje. Zagreb: Medicinska naklada 1999;284-97. (in Croatian)

2. Dolin R. Influenza: current concepts. Am Fam Physician. 1976;14:72-7.

3. Nicholson KG. Clinical features of influenza. Semin Respir Infect. 1992;7:26-37.

4. World Health Organization. World now at the start of 2009 influenza pandemic. Statement to the press by WHO Director-General Dr Margaret Chan. Available at: http://www.who.int/ mediacentre/news/statements/2009/h1n1pandemic-phase620090611/en/index.html.

5. Peiris JS, Poon LL, Guan Y. Emergence of a novel swine-origin influenza A virus (S-OIV) H1N1 virus in humans. J Clin Virol. 2009;45:169-73, http://dx.doi.org/10.1016/j.jcv.2009.06.006. 
6. McLean E, Pebody RG, Campbell C, Chamberland M, Hawkins C, Nguyen-Van-Tam JS, et al. Pandemic (H1N1) 2009 influenza in the UK: clinical and epidemiological findings from the first few hundred (FF100) cases. Epidemiol Infect. 2010;138:1531-41, http://dx.doi.org/10.1017/S09502688100 01366.

7. Cox NJ, Subbarao K. Influenza. Lancet. 1999;354:1277-82, http://dx.doi.org/10.1016/S0140 6736(99)01241-6.

8. Kuzman I. Virusi influence. In: Begovac J, Božinović D, Lisić M, et al., editors. Infektologija. Zagreb: Profil, 2006; p. 490-6. (in Croatian)

9. Oxford JS. Preparing for the first influenza pandemic of the $21^{\text {st }}$ century. Lancet Infect Dis. 2005;5:129-31, http://dx.doi. org/10.1016/S1473-3099(05)01288-0.

10. Nicholson KG, Wood JM, Zambon M. Influenza. Lancet. 2003;362:1733-45, http://dx.doi.org/10.1016/S0140-6736(03) 14854-4.

11. Suarez DL. Evolution of avian influenza viruses. Vet Microbiol. 2000;74:15-27.

12. Capua I, Alexander DJ. Avian influenza infections in birds moving target. Influenza. 2007;1:11-8, http://dx.doi.org/ 10.1111/j.1750-2659.2006.00004.x

13. Savić V. Influenca ptica i drugih životinja. Medicus. 2011;3: 19-23. (in Croatian)

14. Kawaoka Y, Chambers TM, Sladen WL, Webster RG. Is the gene pool of influenza viruses in shorebirds and gulls different from that in wild ducks? Virology. 1988;163:247-50, http:// dx.doi.org/10.1016/0042-6822(88)90260-7.

15. Centers for Disease Control and Prevention. Swine influenza A (H1N1) infection in two children, Southern California, March-April 2009. MMWR. 2009;58:400-2.

16. Webster RG, Yakhno M, Hinshaw VS, Bean WJ, Murti KG. Intestinal influenza: replication and characterization of influenza viruses in ducks. Virology. 1978;84:268-78.

17. Centers for Disease Control and Prevention (CDC) Interim Guidance for Clinicians on the Prevention and Treatment of Swine-Origin Influenza Virus Infection in Young Children. Available at: http://www.cdc.gov/swineflu/childrentreatment. htm. Accessed: April 30, 2009.

18. Khandaker G, Zurynski Y, Buttery J, Marshall H, Richmond PC, Dale RC, et al. Neurologic complications of influenza $\mathrm{A}(\mathrm{H} 1 \mathrm{~N} 1) \mathrm{pdm} 09$ : surveillance in 6 pediatric hospitals. Neurology. 2012 Oct 2;79(14):1474-81, http://dx.doi.org/10.1212/ WNL.0b013e31826d5ea7.

19. Gilbert M, Xiao X, Domenech J, Luborth J, Martin V, Slingenbergh J. Anatidae migration in the western Palearctic and spread of highly pathogenic avian influenza H5N1 virus. Emerg Infect Dis. 2006;12:1650-6, http://dx.doi.org/10.3201/ eid1211.060223.

20. Draženović V, Barišin A. Virusi influence-osobitosti cirkulirajućih sojeva u sezoni 2010/11. Medicus 2011; 1;5-7. (in Croatian)
21. Brown IH. The epidemiology and evolution of influenza viruses in pigs. Vet Microbiol. 2000;74:29-46.

22. Webster RG, Bean WJ, Gorman OT, Chambers TM, Kawaoka Y. Evolution and ecology of influenza A viruses. Microbiol Rev. 1992;56:152-79.

23. Ito T, Kawaoka Y. Host-range barrier of influenza A viruses. Vet Microbiol. 2000;74:71-5.

24. Matrosovich M, Stech J, Klenk HD. Influenza receptors, polymerase and host range. Rev Sci Tech. 2009;28:203-17.

25. Puljiz I, Kuzman I. Gripa - uvijek aktualna bolest. Medicus. 2005;14:137-46. (in Croatian)

26. Smith NM, Bresee JS, Shay DK. Prevention and control of influenza. Recommendation of the Advisory Committee on Immunisation Practices (ACIP). MMWR Recomm Rep. 2006; 55:1-42.

27. World Health Organization. Resolution WHA58.3: Revision of the International Health Regulations 2006. Available at: http:/www.who.int/ipes/publications/wha/ihr resolution.pdf

28. World Health Organization. Global influenza virological surveillance. Available at: http://www.who.int/csr/disease/influenzanetwork/en

29. Lesnikar V. Epidemiološko praćenje influence. Medicus. 2011; 14:95-9. (in Croatian)

30. Kuzman I. Influenca: klinička slika bolesti i komplikacije. Medicus. 2011;5:25-31. (in Croatian)

31. World Health Organization (2009) Clinical management of human infection with pandemic (H1N1) 2009: Revised guidance. Available at: http://www.who.int/csr/resources/publications/swineflu/clinical_management/en/index.html. Accessed 10 September 2014.

32. Marušić M, Petrovečki M, Petrak J, Marušić A. Uvod u znanstveni rad u medicine. Zagreb: Medicinska naklada, 1996; p. 70-4. (in Croatian)

33. Donaldson LJ, Rutter PD, Ellis BM,Greaves FE, Mytton OT, Pebody RG, et al. Mortality from pandemic A/H1N1 2009 influenza in England. BMJ 2009; 339:b5213.

34. Winchester CC, Macfarlane TV, Thomas M, Price D. Antibiotic prescribing and outcomes of lower respiratory tract infection in UK primary care. Chest. 2009;135:1163-7, http:// dx.doi.org/10.1378/chest.07-2940.

35. Gastañaduy AS, Bégué RE. Experience with pandemic 2009 $\mathrm{H} 1 \mathrm{~N} 1$ influenza in a large pediatric hospital. South Med J 2012; 105:192-8, http://dx.doi.org/10.1097/SMJ.0b013e3182 501475

36. Wieching A, Benser J, Kohlhauser-Vollmuth C, Weissbrich B, Streng A, Liese JG. Clinical characteristics of pediatric hospitalizations associated with 2009 pandemic influenza a (H1N1) in Northern Bavaria, Germany. BMC Res Notes 2012; 5(1): 304, http://dx.doi.org/10.1186/1756-0500-5-304.

37. Vaillant L, La Ruche G, Tarantola A, Barboza P. Epidemiology of fatal cases associated with pandemic H1N1 influenza 2009. Eurosurveillance. 2009;14:1-6, http://dx.doi.org/10.2807/ese. 14.33.19309-en. 
38. Patel M, Dennis A, Flutter C, Khan Z. Pandemic (H1N1) 2009 influenza. Br J Anaesth. 2010;104:128-42, http://dx.doi. org/10.1093/bja/aep375

39. Lera E, Wörner NT, Sancosmed M, Fàbregas A, Casquero A, Melendo S, et al. Clinical and epidemiological characteristics of patients with influenza A (H1N1) 2009 attended to at the emergency room of a children's hospital. Eur J Pediatr. 2011; 170:371-8, http://dx.doi.org/10.1007/s00431-011-1399-4.

40. Chen Y, Shang S, Tang Y, Zhang C, Tong M, Dai Y. Clinical features of severe influenza A (H1N1) virus infection. Ind Pediatr J. 2013;80:97-101, http://dx.doi.org/10.1007/s12098012-0784-y.
41. Fabbiani M, Sali M, Di Cristo V, Pignataro G, Prete V, Farina $\mathrm{S}$, et al. Prospective evaluation of epidemiological, clinical, and microbiological features of pandemic influenza A (H1N1) virus infection in Italy. J Med Virol. 2011;83:2057-65, http:// dx.doi.org/10.1002/jmv.22231.

42. Bradarić N, Klišmanić Z, Ivić I, Brzović M. Pandemijska influenca A(H1N1)2009. u Splitsko dalmatinskoj županiji 2009/ 2010. i 2010/2011: neke kliničke i epidemiološke značajke. Medicus. 2011;20:69-76. (in Croatian)

43. Tešović G, Stemberger L. Complications influenzae in children. Medicus. 2011;1:39-44.

Sažetak

\title{
PANDEMIJSKA INFLUENCA A (H1N1) 2009.: BLAGA BOLEST U HOSPITALIZIRANE DJECE U NAJVEĆOJ KLINICI ZA INFEKTIVNE BOLESTI U HRVATSKOJ
}

\author{
S. Grgić, E. Čeljuska-Tošev, J. Nikolić, F. Markotić, M. Vukojević, H. Bebek-Ivanković i I. Kuzman
}

Pandemijski virus influence A (H1N1) 2009. uzrokuje bolest koja se epidemiološki i klinički ne razlikuje značajno od sezonske gripe, ali ipak postoje razlike. Cilj studije bio je prikazati i usporediti epidemiološke i kliničke karakteristike u djece s dokazanim pandemijskim virusom influence A (H1N1) 2009. U Klinici za infektivne bolesti Dr. Fran Mihaljević u Zagrebu u prve dvije sezone incidencija pandemijskog virusa influence A (H1N1) posebno je bila iscrpno analizirana samo u bolesnika s dokazanim pandemijskim virusom influence $A(H 1 N 1)$. U hospitalizirane djece s dokazanim pandemijskim virusom influence A prevladavao je umjereni oblik bolesti, što je u konačnici značilo kraći boravak u bolnici i manje komplikacija. Upala srednjeg uha je bila najrjeđa komplikacija kod djece. Zaključno, djeca mlađa od 5 godina, osobito dječaci, češće su obolijevali od pandemijskog virusa influence A (H1N1), koja se prezentirala kao blaža bolest s niskom smrtnošću i rjeđim komplikacijama. Većina oboljele djece od pandemijske influence nisu imala čimbenike rizika kao što su astma i pretilost, što drugi autori u svojim istraživanjima ističu kao važne čimbenike rizika za virus influence.

Ključne riječi: Influenca A virus; Podtip H1N1; Hrvatska; Rizični čmbenici; Dijete 